\title{
THE COMPARATIVE STUDY BETWEEN READING STRATEGIES USED BY SUCCESSFUL AND UNSUCCESSFUL STUDENTS
}

\author{
Putri Amanda Gustiana \\ University of Bengkulu \\ putriamandagustiana@gmail.com \\ Rudi Afriazi \\ University of Bengkulu \\ Rudiafriazi88@gmail.com \\ Hilda Puspita \\ University of Bengkulu \\ Puspita.hilda@gmail.com
}

\begin{abstract}
ABSTRAK
Penelitian ini bertujuan untuk mengetahui strategi-stategi yang digunakan mahasiswa Program Studi Pendidikan Bahasa Inggris dalam belajar membaca Bahasa Inggris. Penelitian ini dilakukan dengan menerapkan model penelitian perbandingan. Populasi dalam penelitian ini adalah $\mathbf{7 4}$ mahasiswa Program Studi Pendidikan Bahasa Inggris di Universitas Bengkulu tahun akademik 2015/2016. Sampel dalam penelitian ini adalah 74 mahasiswa yang terdiri dari 59 mahasiswa sukses dan 15 mahasiswa tidak sukses. Dan itu merupakan semua dari total populasi. Data dikumpulkan dengan menggunakan angket dan dokumentasi. Angket tersebut terdri dari 45 pernyataan tentang strategi belajar membaca bahasa Inggris yang berdasarkan teori dari Oxford (1990) yang terdiri dari enam kategori dari strategi membaca Bahasa Inggris. Keenam kategori tersebut yaitu, strategi terkait ingatan, metakognitif, kognitif, kompensasi, afektif dan social. Instrument yang digunakan pada penelitian ini merupakan adoptasi dari angket Tabehinejad (2015). Sedangkan instrument dokumentasi merupakan transkrip nilai mahasiswa. Hasil dari penelitian ini menunjukan bahwa antara mahasiswa yang tidak sukses dan sukses di Program Studi Pendidikan Bahasa Inggris menggunakan seluruh kategori dari strategi membaca bahasa Inggris tersebut. Strategi yang paling sering digunakan oleh mahasiswa tidak sukses dalam belajar membaca bahasa Inggris adalah strategi kognitif dan sosial. Sedangkan Strategi yang paling sering digunakan oleh mahasiswa sukses dalam belajar membaca bahasa Inggris adalah strategi sosial.

Kata kunci: Strategi Belajar membaca Bahasa Inggris, Mahasiswa tidak sukses, Mahasiswa sukses
\end{abstract}




\begin{abstract}
The aim of this research was to find out the strategies used by the English Education Study Program students in learning reading skill. The research was designed as a comparative research. The population of the research was 74 students of English Education Study Program of Universitas Bengkulu in the 2015/2016 academic year. The samples were 74 students which consist of 59 successful students and 15 unsuccessful students, taken all of the total population. The data were collected by using a set of questionnaire and documentation. There were 45 statements of reading learning strategies which consisted of six categories of learning strategies proposed by Oxford (1990). They were Memory related, metacognitive strategy, cognitive strategy, compensation and social affective strategy. The instrument of this research was adopted from Tabehinejad (2015). Meanwhile documentation instrument was transcript score from the sixth semester English Education Study Program. The result of this study showed between unsuccessful and successful students of English Education Study Program preferred to use all category of that learning strategy. In addition, the most frequently used strategy group by unsuccessful students was social and cognitive strategy. Meanwhile successful students used strategy group was social strategy.
\end{abstract}

\title{
Keywords: Reading Strategy, Unsuccessful Students, Successful Students
}

\section{INTRODUCTION}

Strategy is an important tool for the language learner. It will make easy in language learning. The strategies result in language learning can improve proficiency. In accordance with the opinion if appropriate language learning strategies result in improved proficiency and greater self-confidence (Oxford, 1990). The strategy is especially important for language learning as tools for active, self-directed involvement, which is essential for developing communicative competence (Oxford, 1990). The strategy can apply for four skills in language learning such as reading, writing, listening, and speaking. One of skill is reading which important in learning the reading process.

Reading is an important skill in life. It becomes a basic skill in the learning process, both in learning generally as well as learning at school. Reading is very important because it can develop the thinking process and helps the reader to discover new things and new information. Consequently, reading helps in enhancing the knowledge (Davis, 2016).

The measurements of reading results can be seen from the successful and the unsuccessful students in the learning process. According to Lawendatu (2013), the success a benchmark measure of the learning achievement level. It refers to the basic competencies and defined competency standards that characterize the mastery of concepts or skills that can be observed and measured. Meanwhile, the success of reading also can be influenced by the reading strategy chosen by the reader. The strategy chosen may help students in comprehending reading text. Learning strategies are highly correlated to the goals of reading. Those strategies can lead the student to be a successful or an unsuccessful reader in the reading process. The success of reading can be measured if students can 
fulfill the characteristic of a successful learning.

The characteristic of the successful reading in general, the students must get $A$ score in reading course. On the other hand, the criteria unsuccessful reading is for students who get a score lower than $A$, they are $B, C, D$, and $E$. So if the students do not fulfill the criteria they cannot achieve the success criteria of learning. This is inversely proportional to the meaning of success.

Reading strategies play an important role in defining the success of reading. Reading strategy is a part of the learning strategy which can comprehend reading text properly and easily in accordance if reading strategies are using by readers to comprehend texts better (Paris, Wasik \& Turner, 1991). Reading strategies designing helps the students to improve their reading skill and make them the active and purposeful readers. So they can achieve their academic needs.

There are some reading strategies divided by Oxford (1990) into metacognitive, cognitive, compensation, memory related, social and affective strategy. Whereas Carrel (1989) divided into two classes global strategies and local strategies. There are some of the reading strategies researches done by some of researcher which indicate that reading strategies have improved the reading skill and given the effect of changes in reading skills.

In English Education Study Program of Universitas Bengkulu, reading is considered to be very important. As students of English Education Study Program, the reading skill supposed to be mastered in order to have the good capability in comprehension; especially if they have the reading strategies which can increase the reading skill. They need to have good reading strategy because they are English learners who are trained to become the English educators or English teachers. By having good reading strategy, it will be good for their language learning and acquisition. It can also be very useful for them to open more opportunities to get scholarships and students' exchange programs, because reading is one of skills includes in TOEFL/TOIEC and one of the criteria to get scholarships or students' exchange programs is the high TOEFL/TOIEC score.

In English education study program, reading is a compulsory and tiered subject taught in third semesters. It is taught in three classes: General Reading, Academic Reading and Extensive Reading. These courses should be taken to get a higher-level of reading course so that their reading ability can be developed. The students are required to finish all three classes as the primary subjects. They cannot take the next level of reading class if they do not pass the previous class with the minimum score of $D$ from $A$.

Based on informal interview and observation, there are some obstacles found in the reading class. First, the students have lack of reading interest. Students' reading ability is still below the expectation. It can be seen on students' ability in making their assignment which are still lacking of reference due to the lacking of their reading. They only read the reading text or book if they have an assignment of subject. They rarely read based on their interest when in fact reading interest is important to enhance students' proficiency.

Second, the students are difficult to understand the text when they find meaning in the same words. It is the problem about words that have more than one meaning. In line with the statement of Babaiba (2014), the students have to lack interest in reading. Insufficient vocabulary causes many obstacles in reading. The student should 
have an understanding of vocabulary widely, or he will not solve the problem of understanding.

Third, naturally the students have different ability. Every student does not acquire the reading skills at the same rate. In comprehending, there are some students which are different in determining the main idea for the sentence and meaning of the text. In accordance with Roe (2014) who states that "reading comprehension is to make meaning of what we read", for the students with low ability in comprehending meaning will get low score and become unsuccessful in reading. Meanwhile, the students with high ability will get high score in comprehending meaning and become successful in reading.

Last, the students' proficiency will not be as good as it is supposed to be, because the criteria for scholarship and students' exchange are high score of TOEFL/IELTS and language proficiency. So if the criteria are not fulfilled, the students cannot participate in the scholarship and student exchange program.

Based on the problem above, it may give bad impact to students if it is not fulfill. They will face new problem in reading besides lack of reading skill. The students only able for answering question without comprehending and get the meaning from the text. Because of the impact. Students cannot achieve the high score in TOEFL/TOEIC.

Those problem are commonly found in every education institution. In English study program of Universitas Bengkulu specifically at the sixth semester students also found the same problem. Some of students have the difficulties when comprehend the reading text. This can be seen from the reading score of some students are not successful in reading. They are unsuccessful in reading subject even they already use the reading strategies appropriately. It is because they have less understanding while comprehending text. Besides they also cannot apply the reading strategies meanwhile they know about the reading strategy. Furthermore, they less of knowledge about reading strategy. Certainly, it will influence the reading proficiency. So some students of the sixth semester will categorize as unsuccessful students in reading.

Concerning to the problem above, the researcher will focus on the sixth semester students of English Education Study Program, Universitas Bengkulu because the researcher ever gets the difficulties in reading subject in the same semester, besides the sixth semester students have already taken all of reading courses. So the researcher can investigate the result of their differences in their proficiency development.

In this research, the researcher will take reading strategy based on the theory of Oxford (1990) who divided reading strategy into six categories: metacognitive, cognitive social, memory related, compensatory, social and affective. Based on these theories, the researcher will do the research about the kinds of reading strategies used, the kinds of reading strategies more frequently used, the reasons of students become successful and unsuccessful students in using reading strategy. In this study, the questionnaire and document will be chosen as the instruments, because these instruments can be the appropriate tool to achieve the answer of research question.

There is some previous study similar with this research. Afdaleni (2013) found that the language learning strategy used by learners in reading comprehension are memory, cognitive, compensation, meta- 
cognitive, affective and social strategies. Besides that, he also found that the influential factors of the learners in using certain language learning strategy are motivation, gender, task, reading material, teaching media, classroom activities and management, and teacher approach and strategy.

It has some differences with Nasab's (2014) research that indicated the metacognitive group significantly outperformed the other groups, so metacognitive strategies were more in line with EFL learners' reading comprehension. Xiaomei (2010) with the title "Comparative Study of Successful and Unsuccessful College ESL Readers in their use of Reading Strategies". The result of this study showed that student's use of metacognitive, social and affective reading strategies. The study also examined and revealed the differences and the similarities of reading strategies use existing within the same group.

This research will be different from the previous studies in term of content. The difference is not only in the content, but also in the result because the different respondents will give different results. Moreover, the strategies chosen is also different with the previous study. At last, the researcher will conduct a research entitled Comparative Study Between Reading Strategies used by Successful and Unsuccessful Students.

\section{METHOD}

This research was a comparative design. It meant the researcher conducted the research at the university directly to find the similarities and differences about things, people, procedures, idea and compare it. According to Arikunto (1997) mentioned that "Comparative research will find similarities and differences about things, people, work procedures, ideas, critical of people, groups, of an idea or a working procedure

The data of this study was analyzed by quantitative method. The quantitative method was used since the researcher needed to find the percentage result of the data. Muijs (2004:2) quantitative research is essentially about collecting numerical data to explain a particular phenomenon.

The population of this research was the sixth semester of English Education Study Program UNIB Academic years2015/2016, classes $A$ and $B$. the total numbers of students were 74 students. Arikunto (2003) suggested if the population is consisted of less than 100 , it is better to take all population. On the other hand, if the number of population is more than $100,10-$ $15 \%$ or $20-25 \%$ of population can be used as a sample. In this research, the researcher used all population became sample.

The instrument of this research were questionnaire and documentation. Questionnaire divided into cloze ended and open ended questions. Cloze ended question to answer the research questions for strategy used. Meanwhile for open ended question to find the students reason. And documentation for find the successful and unsuccessful students

After getting the data, the researcher used some steps in analyzing the data as the follow:

1. Asked for a Research Permit from the English study program chairman to request data of sixth-semester students

2. Took the data about reading subject score of the sixth semester from Academic Division.

3. Separated the result between unsuccessful and the successful students. With the average score B. 
more than $B$ is categorizing into

successful and less that B

categorizing into unsuccessful

students

4. Contacted the sixth semester as the sample of the research.

5. Tried out of the questionnaire before giving the questionnaire to the all research sample

6. Revised the questionnaire, the result will be given to the supervisors to see whether it needs to be constructed properly.

7. Distributed the questionnaire will be given to the samples and it will be taken and counted to know which reading strategy is dominant and being preferred, and the differences between the unsuccessful and the successful strategy

8. The data was analyzed based on quantitative method and Categorizing the result with table

$\mathrm{P}=\frac{F}{N} \times 100 \%$

Where:

$\mathrm{P}=$ the percentage of respondents' answer

$F=$ frequency of the respondents

$\mathrm{N}=$ the total number of respondents

Table 1. Reading Strategy Category

\begin{tabular}{|c|c|}
\hline Class & Category/Predicate \\
\hline $3.28-4.0$ & Always \\
\hline $2.52-3.27$ & Often \\
\hline $1.76-2.51$ & Seldom \\
\hline $1.0-1.75$ & Never \\
\hline
\end{tabular}

9. Categorizing the answer of students which have the same meaning into the same category
10. After completed the data, the result of it compared between two variables until getting valid data.

11. Finally analyzed and compared the descriptive statistical analysis to calculate the weighted mean and percentage

\section{RESULT AND DISCUSSION}

\section{Result}

Reading Strategy Used by Successful and Unsuccessful Students

The result of this research showed that the average use of the six strategy categories (Oxford. 1990) on the questionnaire by unsuccessful and successful students.

Table 2. The Result for Reading Strategy Categories by Unsuccessful Students

\begin{tabular}{|c|c|c|c|}
\hline Strategies & $\begin{array}{c}\text { Mean } \\
\text { Score }\end{array}$ & $\begin{array}{c}\text { Percent } \\
\text { age }\end{array}$ & Category \\
\hline Cognitive & 3.03 & $18 \%$ & High \\
\hline Social & 3.03 & $18 \%$ & High \\
\hline $\begin{array}{c}\text { Compensa } \\
\text { tion }\end{array}$ & 3.02 & $16 \%$ & High \\
\hline $\begin{array}{c}\text { Meta- } \\
\text { cognitive }\end{array}$ & 2.88 & $16 \%$ & High \\
\hline $\begin{array}{c}\text { Affective } \\
\text { Memory } \\
\text { Related }\end{array}$ & 2.81 & $16 \%$ & High \\
\hline \multicolumn{1}{|c|}{ Among unh } \\
\hline
\end{tabular}

Among unsuccessful students,) Cognitive strategy and Social strategy ( $M=3.03$ $(M=3.03)$ appear to be the most frequently used strategies by the students to promote their English reading skill, followed by Compensation strategy $(M=3.02)$, Metacognitive strategy ( $M=2.88)$, Metacognitive strategy ( $M=2.95)$, Affective $(\mathrm{M}=2.81)$ and Memory Related strategy $(\mathrm{M}=3.12)$. 


\begin{tabular}{|}
$\begin{array}{c}\text { Fable } \\
\text { Ite } \\
\boldsymbol{m}\end{array}$ & $\begin{array}{l}\text { List of Unsuccessful } \\
\text { Strategies } \\
\text { Statement }\end{array}$ & $\begin{array}{c}\text { Students } \\
\text { Classified } \\
\text { strategy }\end{array}$ & Mean \\
\hline \multicolumn{1}{|c|}{ unsuccessful Students } \\
\hline 11 & $\begin{array}{l}\text { I read a story or } \\
\text { dialogue several } \\
\text { times until I can } \\
\text { understand it. }\end{array}$ & $\begin{array}{l}\text { Cognitive } \\
\text { Strategy }\end{array}$ & 3.30 \\
\hline 13 & $\begin{array}{l}\text { I write personal } \\
\text { notes, messages, } \\
\text { letters, or } \\
\text { reports in the } \\
\text { new language }\end{array}$ & $\begin{array}{l}\text { Cognitive } \\
\text { Strategy }\end{array}$ & 3.26 \\
\hline & $\begin{array}{l}\text { I work with } \\
\text { other language } \\
\text { learners to } \\
\text { practice or share } \\
\text { information. }\end{array}$ & $\begin{array}{l}\text { Social } \\
\text { Strategy }\end{array}$ & 3.26 \\
\hline
\end{tabular}

the highest weighted mean of individual strategy used by unsuccessful students of the sixth semester was item number 42 (I work with other language learners to practice or share information). This statement included in social strategy with $(M=3.37)$. So, from all of the strategy indicated that unsuccessful student prefer to use other language learners to practice or share information as the strategy in reading.

\section{- Cognitive Strategy}

This strategy consists of practicing, receiving and sending message, analyzing and reasoning, creating structure for input and output. Based on the result, successful student used all strategy, but they more prefer chose "I read a story or dialogue several times until I can understand it" statement as the most frequently strategy used by unsuccessful student. This statement including in practicing in strategy because they used to read several times until understand. This strategy makes them easy to apply in reading.

\section{- Social Strategy}

This strategy consists of asking questions, cooperating with other, talking with a native-speaking conversation partner, and exploring cultural and social norms. Based on the result, Unsuccessful student used all strategy, but they more prefer chose "I work with other language learners to practice or share information" statement as the most frequently strategy used by unsuccessful student. This statement including in cooperating with other in the strategy because they used practice and share information. This strategy makes them easy to apply in reading.

Table 4. The Result for Reading Strategy Categories by Successful Students

\begin{tabular}{|c|c|c|c|}
\hline Strategies & $\begin{array}{c}\text { Mean } \\
\text { Score }\end{array}$ & $\begin{array}{c}\text { Percent } \\
\text { age }\end{array}$ & Category \\
\hline Social & 3.10 & $18 \%$ & High \\
\hline Cognitive & 3.01 & $17 \%$ & High \\
\hline $\begin{array}{c}\text { Compensa } \\
\text { tion }\end{array}$ & 2.97 & $17 \%$ & High \\
\hline Affective & 2.87 & $16 \%$ & High \\
\hline $\begin{array}{c}\text { Meta- } \\
\text { cognitive }\end{array}$ & 2.77 & $16 \%$ & High \\
\hline $\begin{array}{c}\text { Memory } \\
\text { Related }\end{array}$ & 2.75 & $16 \%$ & High \\
\hline
\end{tabular}

Among successful students, Social strategy $(M=3.10)$ appear to be the most frequently used strategies by the students to promote their English reading skill, followed by Cognitive strategy ( $M=3.01)$, Compensation strategy ( $M=2.97)$, Cognitive strategy (M=3.08), Affective strategy $(M=2.87)$, Metacognitive strategy $(M=2.77)$ and Memory Related strategy $(\mathrm{M}=2.75)$. 
Table 5. List of Successful Students' High Used

\begin{tabular}{|c|c|c|c|}
\hline \multicolumn{4}{|c|}{ Strategies } \\
\hline $\begin{array}{c}\text { Ite } \\
m\end{array}$ & Statement & $\begin{array}{c}\text { Classified } \\
\text { strategy }\end{array}$ & Mean \\
\hline \multicolumn{4}{|c|}{ successful Students } \\
\hline 42 & $\begin{array}{l}\text { I work with } \\
\text { other } \\
\text { language } \\
\text { learners to } \\
\text { practice or } \\
\text { share } \\
\text { information. }\end{array}$ & $\begin{array}{c}\text { Social } \\
\text { Strategy }\end{array}$ & 3.37 \\
\hline 23 & $\begin{array}{l}\text { I taking } \\
\text { notes to help } \\
\text { me to recall } \\
\text { important } \\
\text { details. }\end{array}$ & $\begin{array}{c}\text { Compensa } \\
\text { tion } \\
\text { Strategy }\end{array}$ & 3.27 \\
\hline 40 & $\begin{array}{l}\text { I ask other } \\
\text { people to } \\
\text { verify that I } \\
\text { have } \\
\text { understood } \\
\text { or said } \\
\text { something } \\
\text { correctly. }\end{array}$ & $\begin{array}{c}\text { Social } \\
\text { Strategy }\end{array}$ & 3.25 \\
\hline
\end{tabular}

individual strategy used by successful students of the sixth semester was item number 11 (I read a story or dialogue several times until I can understand it). This statement included in cognitive strategy with $(M=3.30)$. Different with unsuccessful students, they used cognitive strategies as the most strategy used. So, in overall the strategy cognitive strategy indicated that successful student prefer to read several times until understand as the strategy in reading.

\section{- Social Strategy}

This strategy consists of asking questions, cooperating with other, talking with a native-speaking conversation partner, and exploring cultural and social norms. Based on the result, Unsuccessful student used all strategy, but they more prefer chose "I work with other language learners to practice or share information" statement as the most frequently strategy used by unsuccessful student. This statement including in cooperating with other in the strategy because they used practice and share information. This strategy makes them easy to apply in reading.

\section{The Most Frequently Reading Strategy Used by Successful and Unsuccessful Students}

the data about the use of strategy in learning reading skill by the successful and successful students of the sixth semester English Education program. The data are presented as follow:

Table 6. The Most Frequently Reading Strategy Used

\begin{tabular}{|c|c|c|c|c|c|c|c|}
\hline $\begin{array}{l}\text { Stude } \\
\text { nts } \\
\text { group }\end{array}$ & $\begin{array}{l}\text { Mem } \\
\text { ory } \\
\text { relate } \\
\text { d } \\
\text { strate } \\
\text { gy }\end{array}$ & $\begin{array}{l}\text { Cogn } \\
\text { itive } \\
\text { strat } \\
\text { egy }\end{array}$ & $\begin{array}{l}\text { Co } \\
\text { mp } \\
\text { ens } \\
\text { atio } \\
\text { nstr } \\
\text { ate } \\
\text { gy }\end{array}$ & $\begin{array}{c}\text { Metac } \\
\text { ognitiv } \\
\text { e } \\
\text { strateg } \\
\text { y }\end{array}$ & $\begin{array}{l}\text { Affe } \\
\text { ctive } \\
\text { strat } \\
\text { egy }\end{array}$ & $\begin{array}{c}\text { Social } \\
\text { strate } \\
\text { gy }\end{array}$ & $\begin{array}{c}\text { Over } \\
\text { all } \\
\text { strat } \\
\text { egy }\end{array}$ \\
\hline $\begin{array}{l}\text { Unsu } \\
\text { ccessf } \\
\text { ul } \\
\text { stude } \\
\text { nts }\end{array}$ & 2.72 & 3.03 & $\begin{array}{l}3.0 \\
2\end{array}$ & 2.88 & 2.81 & 3.03 & 2.92 \\
\hline $\begin{array}{l}\text { Succe } \\
\text { ssful } \\
\text { stude } \\
\text { nts }\end{array}$ & 2.72 & 3.01 & $\begin{array}{l}2.9 \\
7\end{array}$ & 2.77 & 2.87 & 3.1 & 2.91 \\
\hline
\end{tabular}

The result showed that unsuccessful students most frequently used Social strategy and Cognitive strategy $(\mathrm{M}=3.03)$ to promote their learning reading skill, followed by Compensation strategy ( $M=$ 
3.02), Metacognitive strategy ( $M=2.88)$, Affective strategy $(M=2.81)$, and Memory Related strategy $(M=2.72)$.

In addition, successful students most frequently used social strategy ( $M=3.03)$ to gain their learning reading skill, followed by Cognitive strategy $(M=3.01)$, Compensation strategy $(M=2.97)$, Affective strategy $(M=2.87)$, Metacognitive $(M=2.77)$ and Memory Related ( $M=2.75)$.

In overall strategy, the most frequently used the strategies in learning reading skill was the unsuccessful students $(M=2.92)$. It indicated unsuccessful students were highly used the reading strategy. While highest weighted mean was the successful students $(M=2.91)$. It indicated successful students were also highly used the reading strategy. In conclusion, on total number of the students tended to use reading strategy with predicate "High". It indicated the students of English Education Study Program in Universitas Bengkulu High used the learning strategies proposed by Oxford (1990).

\section{Reasons of students become the successful and the unsuccessful readers in using the reading strategy.}

There were some of common reasons students can became successful and unsuccessful students in using reading strategy. For Successful students thought that students can become successful and unsuccessful students in using reading strategy because of students tend to make opinion' statement if students from successful and unsuccessful students because Students are different in using reading strategies, students have different knowledge in vocabulary, students have different motivation, students using appropriate strategy to make them easy in applying strategy, students have different way in using and applying strategy, students mastering the strategy their used well, students have different concentration in applying reading strategy, students think reading strategy do not important because cannot improve their reading skill, so they do not want to use reading strategy and students do not know about reading strategy so they cannot applying it in reading strategy.

Meanwhile Unsuccessful students thought that students can became successful and unsuccessful students in using reading strategy because of students tend to make opinion' statement if students from successful and unsuccessful students because Students are have different knowledge in vocabulary, Students using appropriate strategy to make them easy in applying strategy, Students using appropriate strategy to make them easy in applying strategy, Students just know about strategy but do not know how to applying reading strategy well, Students have different motivation, Students just know about strategy but do not know how to applying reading strategy well, Students have different focus on learning and applying reading strategy, Students think reading strategy do not important because cannot improve their reading skill, so they do not want to use reading strategy, and Students do not know about reading strategy so they cannot applying it in reading strategy.

In conclusion between unsuccessful and successful student have some similar and also different reason but there had same meaning and purposes reason for students can become unsuccessful and successful used their reading strategy. 


\section{Discussion}

Based on the result the highest frequency of individual statement used by Unsuccessful and Successful students was "I work with other language learners to practice or share information". One of the possible reasons is because the unsuccessful students need to understand or learn the way the native speaker reading English in order to practice or gain a better comprehending in reading English. According to Katie (2016) achieving native-level fluency is a lofty goal. It means the students when they perceive into higher level of learning, they are going to set higher goal too because at this rate the students' orientation have already realistic. They are going to find the strategy in which they can explore themselves to achieve their purpose in learning. One of that purposes was when they can increase reading skill in comprehending the text. One of the way which can increases to comprehend the text is practicing more.

Meanwhile the lowest frequent of individual statement used by Unsuccessful and Successful was "I read a story or dialogue several times until I can understand it". One of the possible reason it is because repeating when read is one of the easy way in cognitive strategy which often to do in getting meaning of the text. So many of successful students done repeating as one the way to completing the strategy their used. One of way in cognitive opinion from Bayat (2010) Surface cognitive strategies refer to rehearsal, involving the repetitive rehearsal and rote memorization of information, which helps to encode new information into short-term memory, mainly through reading the course material over and over again. According to Gorsuch (2008) Repetition in reading should be mentioned here that has significant effect on reading fluency vocabulary overlapping between two text should increase reading rate, this effect suggests that automaticity with word. It is showed repeating when reading have the benefit for reader.

As conclusion, the researcher concluded that the students of English Education Study Program preferred to use all of six strategies proposed by Oxford (1990). Although, it is not really significant difference of frequency.

\section{The Most Frequently Reading Strategy Used} by Successful and Unsuccessful Students

Based on the total number of the result showed that the most frequently used strategy by the successful and unsuccessful students English Education Study Program students of Universitas Bengkulu was strategy "I work with other language learners to practice or share information". This item has the highest weighted mean of the strategy and included in social strategy. Oxford (1990) social strategies provide learners with the means to interact with other people through improving their understanding and enhancing language production. It also refers the ways in which learners learn the language through interactions with native speakers or the target language, such as asking questions, cooperating with peers and improving cultural understanding situations.

In term of reading learning strategy groups, the most frequent used by unsuccessful students were cognitive strategy with the strategy "reading a story or dialogue several times until understand it" and social strategy with the strategy "working with other language learners to practice or share information" as strategy. Meanwhile successful student has the same strategy. that is social strategy with the strategy "working with other language learners to practice or share information". Although between successful and 
unsuccessful students have the same strategy that is social strategy. Unsuccessful students tended to use cognitive strategy than social strategy. It showed from the result if weighted average of individual unsuccessful student cognitive strategy higher than social strategy.

This finding showed that unsuccessful students more tended to used cognitive strategy than social strategy which can help students in improve reading skill. But different with finding research from Nasab (2015) which showed that metacognitive strategies were more in line with EFL learners in improve reading comprehension. Meanwhile this is accordance with the findings with Afdaeleni (2013) if the language learning strategy used by learners in reading comprehension are affective and social strategies.

The result also showed that the English Education Study Program students preferred to choose all strategies in learning reading skill. It meant that the students of English Education Study Program tended to use all the category of learning strategy in reading skill. This finding is in accordance with Oxford (1990) if several other study findings found the students applied almost all strategies proposed in reading skill.

However, in overall strategy it showed that unsuccessful and successful students of the Education Study Program of Universitas Bengkulu used reading learning strategy in "High" used. This present finding was similar to the findings of Afdaleni (2013) who found the high used social strategy in learning skill among Iran college students. But different Xiaomei (2010) was found that EFL students had high scores in metacognitive strategies The researcher believes that the students of the Education Study Program of Universitas Bengkulu have more opportunity to learn more and practice their reading strategy in reading skill in every situation since they are majoring in English.

As conclusion, the researcher concluded that the unsuccessful students of English Education Study Program preferred to use cognitive and social strategies proposed by Oxford (1990). Meanwhile successful students of English Education Study Program preferred to use social strategy. Although, it is not really significant difference of frequency, the result only provided the prove about most frequently used strategies and the least frequently used strategies since the difference of weighted mean was approximately only 0.01 . It can be caused all of the learning strategy are good to be used. Because learning strategy is good to make as long as it is used appropriately. In line with statement if successful language learners are more flexible and appropriate in their use of learning strategies Bobanović(2011).

Reasons of Students become the Successful and the Unsuccessful Readers in Using the Reading Strategy

As the result above, the researcher sums up the common reason students can become the successful and unsuccessful students in using reading strategy. Reasons influenced by some factors that can make students become the successful and unsuccessful in using reading strategy. They were different in strategy, knowledge, ability motivation, and concentration in using reading strategy. The factor will explain in the following text.

\section{a. Strategy}

Strategy was one of the influential factors of students can become successful and unsuccessful students in using reading strategy.

Many of students indicated that they just understood about the material 
about reading strategy presented to them. But when in implementing they could not be using it well. So, it made some students got difficulties in getting the idea of the lesson and in their reading comprehension. Automatically, those were influencing student proficiency and also student's score in reading skill. Kucukoglu (2012) have found that reading strategies is a key element in developing student comprehension. Besides the research done by Gunther (2006) reading strategies give the impact to African and American students reading achievement. So, it showed that reading strategy influenced reading comprehension and reading achievement.

b. Motivation

Second factors that influence students can become successful and unsuccessful students in using reading strategy was motivation. According to Oxford (1989), who studied the effect of a number of factors on strategy use, including motivation, found motivation as the single most important factor influencing strategy use. Motivation as stated by Brown (2002) was one of the most important factors of the success in learning English. It made the meaning of a real purpose in learning English or really wanting to learn English for a reason.

Moreover, he states that to be successful in the future, you have to understand about your own motivation because it was one of the most important factors in your success especially in learning English. In line with this, Oxford (1990) states that motivated students tended to use more strategies than less motivated students, and the particular reason for studying the language was important in the choice of strategies.

c. Knowledge and Ability

The third factor that influence students can become successful and unsuccessful students in using reading strategy was Knowledge and ability. Sometimes students have the ability in reading skill but they do not have knowledge about reading strategy which can help them to efficient the time in comprehend the text and also more improve their reading skill. Exactly if students have more knowledge they can improve their ability but on the contrary if they have ability it does not mean they can use reading ability as well as. Habibian (2015) states that Students abilities to use effective reading strategies through which they obtain process and retain the knowledge of language. It showed that between knowledge and ability had the relationship in processing language.

d. Concentration

The last factors that influence students can become successful and unsuccessful in using reading strategy was concentration. Some of students less of concentration when applying the reading strategy. So, the result was not maximal and influenced the proficiency of students in reading skill. Butler (2013) states that the focuses on concentration of students under preparedness is their levels of academic literacy (AL) in the 
language of learning at South African universities (mainly English or Afrikaans).

Based on the result showed that which can influence students proficiency not only reading strategy but also there were some factors which also influenced student. Some factors that affect the using of learning strategy. As explanation above, in line with statement from Oxford (1994) identified factors that influenced the choice of learner using language learning strategies including age, gender, learning style, cultural background, type of task, motivation, attitudes, and teacher perception. Besides this finding also in accordance with afdalaeni (2013) if the influential factors of the learners in using certain language learning strategy are motivation, gender, task, reading material, teaching media, classroom activities and management, and teacher approach and strategy.

\section{CONCLUSION AND SUGGESTION}

\section{Conclusion}

This research attempted to acquire deeper understanding about reading strategies used by unsuccessful and successful students at the sixth semester English Education Study Program of Universitas Bengkulu. Analysis of the research findings reveals that the unsuccessful and successful students used varied strategies; memory related, cognitive strategy, Compensation strategy, metacognitive strategy, affective strategy, and social strategy. Here the conclusion of this research

1. The successful and unsuccessful students of English Education Study Program preferred to choose all reading strategy in reading skill. it was because all of the reading strategy are good to be used and there is no reading strategy was bad as long as it is used appropriately. Although there was some of reading strategy used were frequent than other strategy. It was depending on the student themselves which choose the appropriate strategy.

2. The most frequently strategy group used by unsuccessful students of English Education Study Program was cognitive with the strategy" reading a story or dialogue several times until can understand" meanwhile for social strategy with the strategy "working with other language learners to practice or share information". Meanwhile successful students were social strategy with the same strategy with unsuccessful students working with other language learners to practice or share information". This finding is in contrast with several previous studies that found Metacognitive strategy as the most frequently strategy group used by the students. The cause was there were some differences of the previous study, the research question, and the theory of learning strategy that used in the study. Also, these previous study were not concern about reading strategies, for instance they were concern about learning strategy in learning English and its structure.

3. The average reason of students can become successful and unsuccessful in reading strategy because of some factors that affect the using of reading strategy. The form factors were strategy, motivation, concentration, knowledge and ability. But the result for the most opinion was different. So, the 
researcher concluded that the same strategy may not necessarily produce the same results but depend on their motivation, concentration, ability and knowledge. The last how far their effort to fulfill the factor that can influenced their result.

\section{Suggestion}

There are some suggestions that the researcher can propose after doing the analysis as follow:

1. For the Lecturers

- The researcher suggests for the lecturers to design the materials which are corresponded with the students' strategy. It is good for both lectures and the students to get the material based on their learning strategy. It will make the teaching and learning process more effective and more enjoyable. So, the purpose of learning can be achieved successfully.

- The researcher also suggests to lecturers to use collaborative learning for students. This is because the teacher intends to combine successful and unsuccessful students in the learning process. So that the hope for successful students can help explain ways that can improve the ability of unsuccessful students in reading skill and also give a positive influence on unsuccessful students in learning.

2. For the Students

- The researcher suggests for the students to use reading strategy in learning reading skill more appropriately. The students can choose the reading strategy based on their personal needs. It is better for the students to combine all the reading strategy in learning reading skill, in order to be successful in the reading skill. For instance, the students also can ask the lectures for guiding in order to determine the reading strategy appropriately for them based on their learning needs.

3. For Further researcher

- The further researcher to conduct the same scope of research by involving other instruments, such as reading test to surely the score of students which should pure based on their ability. So the next researcher can get valid score. Another option is the further researcher can do the research on reading strategies in different language skills.

- The researcher suggests for the further researcher can conduct the same scope of research but more focusing to investigate the achievement or score of the students which to know the relevant way of the students learn and get.

- The researcher suggests for the further researcher to find the aspects that have not been described by researchers in this research as how to handle the factor that affects students can be successful and not successful in reading skills.

- The researcher also suggests for the further researcher to searching for the most dominant aspect factor affecting students in being successful and not successful in reading skills.

\section{REFERENCES}

Afdaleni (2013). International Review of Social Sciences and 
Humanities.

Language

Learning Strategy in English

Reading Comprehension

Used by Successful and

Unsuccessful Learners at

College. Vol. 5, No. 2 (2013),

pp. 193-202. Bukit Tinggi.

Ayaz (2017). International Journal of Language Academy. The Relationship between EFL Learners' Language Learning Strategy Use, Willingness to Communicate, and L2 Achievement. Vol. 5 CUELT Special Issue September 2017 p. $78 / 92$.

Anonym

Factors Affecting Rea ding Ability in School Age Ch ildren. (Paper presented at.Strategic Marketing \& Res earch, Inc) Los Angles, 2013..

Anderson. Neil J. (1990) Individual Differences in Strategy Use in Second Language Reading and Testing. Volume75, Issue 4.

Babaiba, Wahiba Medjahdi Doctoral Dissertation: "Reading Comprehension Difficulties among EFL Learners: The Case of Third-Year Learners at Nehali Mohamed Secondary School'. Nehali: University of Tlemcen, 2014.

Bayat, Sahar (2010) Assessing Cognitive and Metacognitive Strategies during Algebra Problem Solving Among University Students. Procedia Social and Behavioral Sciences 8 (2010) 403-410

Bobanović, Moira Kostić (2011). Original research paper. A Comparative Study of Language Learning Strategies Used by Successful Monolingual and Bilingual Efl Learners. Vol. 6(3)

Butler (2013). Beyond Cognition: Reading Motivation and Reading Comprehension. Vol. 10, No.3.190-195.

Davis, Glenn (2016). Why reading is important. Retrieved from https://www.learn-to-readprince-george.com/why-isreading-important.html.

Grabe, Stroller (2002). Learning strategy of Turkish Students. Vol. 10, No.3.190-195

Gunther, Noel (2006). Learning dyslexia online. Retrieved from http://www.ldonline.org/inde $\mathrm{pth} /$ research

Habibian, Maryam, Roslan, Samsilah (2015). Journal of Education and Practice. The Role of Psychological Factors in the Process of Reading. Vol.6, No.29.

Katie (September 20, 2016). How to Speak English Like a Native Speaker.Retrieved from https://englishlive.ef.com/blo g/english-in-the-realworld/how-to-speak-englishlike-a-native-speaker/

Kucukoglu, Huyla (2012) Procedia - Social and Behavioral Sciences. Improving Reading Skills Through Effective Reading Strategies. Vol. 70, No.709.

Lai, Ya-Li, Tung, Yu-Jung, Luo, Shu-Ying (2015). Journal of Educational and Instructional Studies in The World. Theory 
of Reading Strategies and its Application by EFL Learners: Reflections on Two Case Studies. Volume: 5 Issue: 3 Article: 03.

Lawendatu, Sarmin. (april 7, 2014). Kriteria Keberhasilan Pembelajaran. Retrieved from https://tugas2kampus.wordpr ess.com/2014/04/07/kriteriakeberhasilan-pembelajaran/

Nasab, Mahdiyeh Seyed Beheshti (2015). Advances in Language and Literary Studies. A Complete Review for Metacognitive, Cognitive, and Social/Affective Strategies as Essential Components of Learning strategies and their relationships with EFL Learners' Reading Comprehension Promotion. Vol. 6 No. 3

Oxford, Rebecca L (2003). Language Learning Styles and Strategies: An Overview. Retrieved from http://www.muslimedianews. com/2016/02/cara-penulisandan-contoh-daftar.html

Sudaryono, Metodologi Penelitian. Jakarta:PT RajaGrafindo Persada. 2017

Suryabrata, Sumadi, Metodologi Penelitian. Jakarta: PT RajaGrafindo Persada. 2003

Suyityo (2017) Cognitive Strategies Use in Reading Comprehension and its Contributions to Students' Achievement.Vol.5, No.3

Talebinejad. Mohammad Reza, Sadeghdaghighi, Akram,
Liaghat, Farahnaz (2015). Theory and Practice in Language Studies. Application of Reading Strategies: A Comparative Study between Iranian and Indian EFL Students. Theory and Practice in Language Studies. Vol. 5, No. 2, pp. 356-363.

Tarnraporn, Songsiengchai thesis: "Strategies in Reading Online and Printed Academic Texts of English Major Students of Srinakharinwirot

University".

Srinakharinwirot:

Srinakharinwirot University, 2010.

Trainin, Guy (2015) Learning Vocabulary with Apps: From Theory to Practice. University of Nebraska.

Trialoka, Venti Septika (2015). English Learners' Strategy in Learning Speaking Skill. Universitas Bengkulu. 2017. (Undergraduate Universitas Bengkulu)

Uzunçakmak, Pinar Master's Thesis: "Successful and Unsuccessful Readers' Use of Reading Strategies". Ankara: Bilkent University, 2005.

Xiaomei, Wang (2010). Journal of Multilingual and Multicultural Development. The sociolinguistic realignment in the Chinese community in Kuala Lumpur: past, present and future. Vol 31, 2010 - Issue 5.

Yang, Xiaoling (2016). Journal of Language Teaching and 
Research. Study on Factors Affecting Learning Strategies in Reading Comprehension. ISSN 1798-4769., Vol. 7, No.

3, pp. $586-590$ 